\begin{tabular}{|c|c|c|c|c|c|c|}
\hline \multirow{4}{*}{ Impact Factor: } & ISRA (India) & $=3.117$ & SIS (USA) & $=0.912$ & ICV (Poland) & $=6.630$ \\
\hline & ISI (Dubai, UAE & $=0.829$ & РИНЦ (Russia) & $=0.156$ & PIF (India) & $=1.940$ \\
\hline & GIF (Australia) & $=0.564$ & ESJI (KZ) & $=8.716$ & IBI (India) & $=4.260$ \\
\hline & JIF & $=1.500$ & SJIF (Morocco) & $=5.667$ & OAJI (USA) & $=0.350$ \\
\hline
\end{tabular}

\section{SOI: $\underline{1.1 / T A S}$ DOI: $\underline{10.15863 / T A S}$ \\ International Scientific Journal Theoretical \& Applied Science}

p-ISSN: 2308-4944 (print) e-ISSN: 2409-0085 (online)

Year: 2019 Issue: $05 \quad$ Volume: 73

Published: $16.05 .2019 \quad \underline{\text { http://T-Science.org }}$

Section 13. Geography. History. Oceanology. Meteorology.
QR - Issue
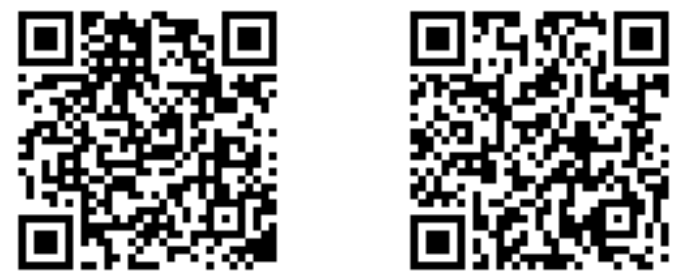

Otabek Yusupdjanovich Aripdjanov

Deputy Director on Scientific Affairs of the State Museum of History of Uzbekistan

\title{
A BRIEF HISTORY OF THE WORKED BONE, IVORY, ANTLER AND HORN OBJECTS FROM BACTRIA IN KUSHAN PERIOD (1st century BC - 4th century AD)
}

Abstract: This paper offers the first systematic study of the artifacts of bone, ivory, antler and horn discovered from the various archaeological contexts of the Kushan period in Bactria. After examining such issues as the sources of the raw material, carving technique, symbolism and functions of the objects, the sisprovides an analysis on the genesis and development of the manufacture of bone and ivory artifacts as well as a complete catalogue of the objects found so far from the archaeological excavations in Bactria. It will also touch upon questions such as distinctions between local production and imports and the social and economic roles of craftsmen in the Bactrian society of the Kushan period.

Key words: Bactria, Kushan period, bone, ivory, carving technique.

Language: English

Citation: Aripdjanov, O. Y. (2019). A brief history of the worked bone, ivory, antler and horn objects from Bactria in Kushan period (1st century BC - 4th century AD). ISJ Theoretical \& Applied Science, 05 (73), 65-67.

Soi: http://s-o-i.org/1.1/TAS-05-73-12 Doi: crossef https://dx.doi.org/10.15863/TAS.2019.05.73.12

\section{Introduction}

The territory of ancient Bactria was huge, it started from the Mountain ranges of Hindu Kush (Afghanistan) to Hissar ridge (appr location is in the south of Uzbekistan and Tajikistan) it was, originally, a small territory in Balkh valley with the capital center in the Bactra city (Northern Afghanistan). Since the second half of the 2 millennium BC proto-city culture was formed in this territory, and later first state associations were recorded. From the middle of the third quarter of the 6th century $\mathrm{BC}$ to $330 \mathrm{BC}$ Bactria as satrapy was a part of the Achaemenid empire. In 329-327 BC it was conquered by Alexander the Great and process of formation of the Hellenistic culture is traced further in material culture of the Kushan empire (I century BC III century AD) which was one of four "world" empires along with Chinese, Parthian and Roman. The Kushan empire flourished at Kanishka I (127150) who, rendered assistance to communities of the northern direction of a Buddhism - Mahayana. And at the end of the first half, more precisely in the middle of the III century AD the Kushan state was stopped by the existence and Bactria - Tokharistan became a part of the Sasanian state as the special possession managed by the members of the Sasanian king's house bore the title of "Kushanshah".

The sources of handicraft production of this time are rather limited. The whole complex of materials allow to speak only about the pottery, blacksmith's work, jeweler productions, weaving, wood and bone work which have developed dynamically at this time.

Today the main source on the bone and ivory manufacture of Bactria in Kushan times are materials of archeological excavations of the ancient cities, settlements, temples, burial grounds and barrows on which excavation has been conducted from the beginning of the 20 century up to the present time. Huge interest has been taken by archaeological researches and excavation on ancient sites as, Aykhanum [1], Begram [2], Surkh-Kotal [3], Takhti-Sangin [4], Dalverzintepa [5], Halchayan [6], Kampyrtepa [7], Zartepa [8], Hayrabadtepa [9], Fayaztepa, Karatepa, etc.

From ancient times the population of Bactria used production of instruments of labor, arms, various items of household and jewelry as initial material incluing; metal, a stone and a tree - bone, ivory, antler and horn. Today there are no a special work on the bone carving business of Bactria 


\begin{tabular}{llllll} 
& ISRA (India) $=\mathbf{3 . 1 1 7}$ & SIS (USA) & $=\mathbf{0 . 9 1 2}$ & ICV (Poland) & $=\mathbf{6 . 6 3 0}$ \\
Impact Factor: & ISI (Dubai, UAE) $=\mathbf{0 . 8 2 9}$ & PUHL (Russia) $=\mathbf{0 . 1 5 6}$ & PIF (India) & $=\mathbf{1 . 9 4 0}$ \\
& GIF (Australia) $=\mathbf{0 . 5 6 4}$ & ESJI (KZ) & $=\mathbf{8 . 7 1 6}$ & IBI (India) & $=\mathbf{4 . 2 6 0}$ \\
& JIF & $\mathbf{1 . 5 0 0}$ & SJIF (Morocco) $=\mathbf{5 . 6 6 7}$ & OAJI (USA) & $\mathbf{0 . 3 5 0}$ \\
\hline
\end{tabular}

in Kushan time. All findings of the bone and ivory production are scattered in tens of articles, books and catalogs, or mainly the most frequently mentioned ones; sometimes they come in only with illustrations, in rare circumstances they are available with detailed descriptions.

\section{Raw Materials}

The study of source of raw materials is one of the major object of studying the bone and ivory manufacture of Bactria - Kushan time, since knowing the peculiar qualities of raw materials can be possible to define from which material the object was made, which in turn will give us the opportunity not only to know a source of raw materials of handicraftsmen of the Kushan period, but also objects of local production and import that will allow to track economic and cultural ties between the East and the West.

The main raw material for bone and ivory manufacture in Kushan time were bones of neat cattle, ivory, antler, horn, perhaps, hippopotamus ivory and bones of other small cattle [10].

All the materials above structurally differ from each other and the processing of them were used a special techniques. In scientific literature, we often find that some researchers, without proper knowledge of structures and specific properties of a bone, ivory and horn the majority objects in archaeological works define them inexact, that is an ivory as a bone or vice versa, it is general concern of bone hairpins, dice, buckles, pyxis, flutes and any handles.

\section{Processing}

The processing of a bone on the techniques has much in common with woodworking and stonemason manufacturing. Masters produced the necessary items in various ways; sawed down, cut off, drilled, trimmed unnecessary parts. It is known that a bone semi-finished products before cutting could boil for the purpose of them to soften. After such processing the bone could be planed with a knife, chipped plates to bend freely. And also from bones of animals and sturgeon fishes boiled various glues [11].

Studying of written sources of the antique time and archaeological material received as a result of excavation in the territory of Bactria allows assuming that all known by the beginning of the 20 century and partially applied and now instruments of labor and ways of processing of a bone were known to masters of antique time.

\section{Typology and interpretation of the objects}

Bone and ivory household items and arms are taking up an extremely important place among archaeological material of Kushan Bactria. Today, despite the available practices, there is still the whole block of questions of typology and interpretation which still remain out of the sphere of attention of researchers. Meanwhile, it is very important generalized comparison of the different categories of items in one era or culture. It opens possibilities of the solution one of the main tasks of this research are to carry out the comparative analysis of collections for identify of characteristics which could serve as indicators of ethno culture and chronological proximity of different groups of monuments or cultures.

One of the most common findings of the bone objects in the territory of Batriya are hairpins with the sharp end and with various types of top pieces [12]. In scientific literature these objects are given various definitions and functions: pins, hairpins, piercing, items for cleaning of ears, etc. but the most common version to consider them as styles for the letter.

On character of images on the top piece can be distinguished in four groups: anthropomorphous, zoomorphic, geometric and floral, in turn, divided into types and variant.

Another type of findings - combs made from bone and ivory in a shape are divided into two groups. These are one-sided and double-sided combs which are in turn divided into types and variant [13].

Dice of an oblong form were quite widely widespread on territories of Central Asia in Kushan time. The area of their distribution can be tracked from Fergana Valley to Khorezm but most often they are found in the territory of Bactria.

The typology and interpretation of the functional purpose of other finds as chess figures, belts, buttons, whorls, figurines, furniture components, handles of swords and knives, overlays for bows and other single finds with undetermined functions will help to create the first in own way overall picture of volume of all subjects.

\section{Export import of raw materials and products of production}

Widely was developed and adopted by foreign trade of Kushan's. They firmly held in the hands the eastern part of the so-called "The Great Silk Way", the main transcontinental road

which provides an international trade with China through oases of East Turkestan to Central Asia and through Iranian Plateau to the countries of East Mediterranean.

According to Pausanias (to Paus. V. 12. 3), the Greeks "brought an ivory from India and Ethiopia in order to make the statues". There is also evidence that Greece along with an ivory from Africa was delivered, the ivory from India, was not an 


\begin{tabular}{llllll} 
& ISRA (India) $=\mathbf{3 . 1 1 7}$ & SIS (USA) & $=\mathbf{0 . 9 1 2}$ & ICV (Poland) & $=\mathbf{6 . 6 3 0}$ \\
Impact Factor: & ISI (Dubai, UAE) $=\mathbf{0 . 8 2 9}$ & PUHL (Russia) $=\mathbf{0 . 1 5 6}$ & PIF (India) & $=\mathbf{1 . 9 4 0}$ \\
& GIF (Australia) $=\mathbf{0 . 5 6 4}$ & ESJI (KZ) & $=\mathbf{8 . 7 1 6}$ & IBI (India) & $=\mathbf{4 . 2 6 0}$ \\
& JIF & $\mathbf{1 . 5 0 0}$ & SJIF (Morocco) $=\mathbf{5 . 6 6 7}$ & OAJI (USA) & $\mathbf{0 . 3 5 0}$ \\
\hline
\end{tabular}

exception, especially, during the Hellenistic period. Also there is information that down the river Amu Darya lived traders and merchants, who conducted maritime and land trade not only with its neighbors, but also from distant countries. So, Dio Chrysostom (around 50-117 AD) was witness of presence in Alexandria, Egypt, which he called the cosmopolitan city, representatives of Bactria, Scythia and India (Dio. Chrys. III, 40).

\section{Conclusion}

The study of written sources of the antique time and archaeological material was received as a result of excavation in the territory of Bactria allows assuming that Bactrian masters knew all receptions and methods of processing of a bone. Unfortunately, until now, carver workshop has not found any on the territory of Bactria, that complicates to make an overall picture of position of the handicraftsman in society, and also in more detail to consider tools and the volume of production of one or another object. But whole complex of findings gives us the chance to assume that the bone and ivory manufacture played an important role among the handicraft industry, not only in ancient Greece, Rome, Egypt and Bactria in antiquity.

\section{References:}

1. Guillaume, O., \& Rougeulle, A. (1987). Fouilles d'AII Khanoum. VII. Les Petits Objets. MDAFA. Paris. Pl. XXIV. 11 (F3).

2. Ghirshman, R. B. (1946). Recherches Archéologiques et Historiques sur les Kouchans. Tome XII. Pl. XXXVII. BG-104.

3. Fussman, G., \& Guillaume, O. (1990). Surkh Kotal en Bactriane. Les Monnaies les Petits Objets. Mémoires de la Délégation Archéologique Française en Afghanistan. Tome XXXII. Volume II. Paris, pp. 133, Planche 8, fig. 568.

4. Litvinskiy, B. A. (2010). Khram Oksa v Baktrii (Yuzhnyy Tadzhikistan). Iskusstvo, khudozhestvennoe remeslo, muzykal'nye instrumenty. Tom 3. Moscow.

5. Pugachenkova, G. A., et al. (1978). Dal'verzintepa. Kushanskiy gorod na yuge Uzbekistana. Tashkent. pp. 39, 59, 60-61, 101, $108,110,111,136-137$. Ris. 8, 9, 21, 36.8-9, 7910,11, 97.

6. Pugachenkova, G., \& Khalchayan, A. (1966). $K$ probleme khudozhestvennoy kul'tury Severnoy Baktrii. Tashkent. p. 96. Ris. 62.

7. Luneva, V. (2005). Yuvelirnoe iskusstvo Severnoy Baktrii (I v. do n.e. - IV v.n.e.). Tashkent. pp. 61-65, 81, 83.
8. Zav'yalov, V. A., \& Osipov, V. I. (1973). Raskopki zhilogo kompleksa na gorodishche Zar-tepa $v 1973$ g. Baktriyskie drevnosti predvaritel'nye soobshcheniya ob arkheologicheskikh rabotakh na yuge Uzbekistana. L. pp. 58. ris. 3,9, 3,10.

9. Zhukov, V. D. (1961). Arkheologicheskaya razvedka na shakhristane Khayrabad-tepa. IMKU, Vyp. 2, p. 186.

10. Aripdzhanov, O. Y. (2016). Kost' - kak osnovnoe syr'e $v$ kostoreznom dele Baktrii $v$ antichnyy period. Moddiy-ma"naviy meros va umumbashariy қadriyatlar. Respublika ilmiy amaliy anzhumani (maқolalar ty̆plami). Tashkent, p.153.

11. Peters, B. G. (1986). Kostoreznoe delo $v$ antichnykh gosudarstvakh Severnogo Prichernomor'ya. Moscow, p. 26.

12. Zav'yalov, V. A. (1993). Kostyanye predmety tualeta iz pamyatnikov Sredney Azii kushanskogo i postkushanskogo vremeni. KSIA. Vyp. 209. Moscow, pp. 31-41.

13. Aripdzhanov, O. Y. (2018). Kostyanye grebni iz Baktrii: novyy vzglyad na ikonografiyu izobrazheniy i tekhniku izgotovleniya. KSIA. Vyp. 250. Moscow, p. 281. 